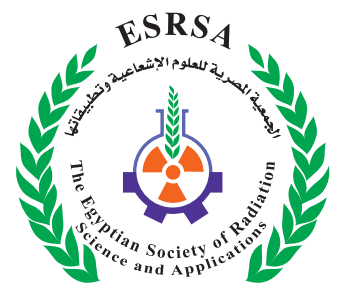

J. Nucl. Tech. Appl. Sci., Vol. 7, PP. 221 : 236 (2019)

\title{
Isolation and Characterization of New Ectoine-Producers from Various Hypersaline Ecosystems in Egypt
}

Omara, A.M.A. ${ }^{1}$; Sharaf, A.M. ${ }^{2}$; El-Hela, A.A. ${ }^{3}$; Shahin, A.A.M. ${ }^{1}$; El-Bialy, H.A. ${ }^{1}$ and El-Fouly, M.Z. ${ }^{1}$

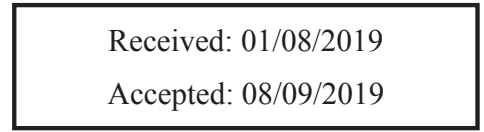

E.nail:elbialyheba@yahoo.com

\section{KEYWORDS}

Ectoine, Halophilic

Bacteria, Hypersaline

Environment, Osmotic

Stress.

\section{ABSTRACT}

The biodiversity of aquatic and terrestrial ecosystems in Egypt including seas, lakes, and soils with high salinity levels provides rich habitats for flourishing halophilic microorganisms. The present study aims to isolate halophilic bacteria from sixteen samples representing ecosystems with various geographic locations and surveying the mechanisms by which they can tolerate the osmotic stress. Results revealed the highest salinity levels; sodium, chloride, sulfate, magnesium, calcium, and potassium concentrations in water sample of Wadi El-Natroun Lake since the total number of halophilic bacteria was 4.68/g and the largest number of halophilic genera was observed in the northern coast of Matrouh governorate. A total of 60 bacterial isolates selected during (June-October 2015) were screened using thin layer chromatography for osmolyte; ectoine. It has the ability to decrease the harmful effects of high salinity, heating, freezing, drying as well as oxygen radicals and other denaturing agents in halophiles. Quantitative estimation of ectoine by high-performance liquid chromatography showed its yield was ranged between 185 and $700 \mathrm{mg} / \mathrm{l}$. Using biochemical tests and 16s rRNA technology, the most active ectoine-producers were identified as Vibrio sp. CS1 and $\mathrm{Sa}$ linivibrio costicola SH3. The yielded ectoine was purified using cation exchange chromatography (Dowex $50 \mathrm{WX}_{8}$ resin) and its physicochemical properties were investigated using standard methodology. Characterization of purified ectoine via nuclear magnetic resonance and fourier transform infrared spectroscopy showed the similarity between bacterial ectoine and the authentic was nearly $99 \%$. .

1. National Center for Radiation Research and Technology (NCRRT), Radiation Microbiology Department, Atomic Energy Authority, Cairo, Egypt.

2. Faculty of Science, Al-Azhar University, Cairo, Egypt.

3. Faculty of Pharmacy, Al-Azhar University, Cairo, Egypt 


\section{INTRODUCTION}

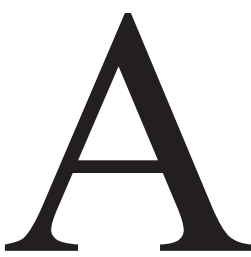

lthough the diversity of natural microorganisms, a low fraction of the total microbial population has been isolated and characterized. Different environments with extreme conditions, such as high/low temperature, high/low $\mathrm{pH}$, high salinity and high pressure, provide distinctive microorganisms with great potential for applications in food, chemicals, and drugs as well as environmental aspects (Orellana et al., 2018).

Halophiles (salt-loving) are referred to microorganisms that require salt for growing and can be found in hypersaline environments, which are widely distributed in various geographical areas on the earth, such as saline lakes, salt pans or salt marshes (Setati, 2010). Halophilic microorganisms have been used in unlimited applications in different biological fields. Many halophiles can produce extracellular hydrolytic enzymes; amylases, lipases, proteases, xylanases, and cellulases which are termed as halophilic hydrolases and capable of catalyzing hydrolytic reactions under high salt concentrations and adverse conditions (Rohban et al., 2009). Some halophiles synthesize polyhydroxyalkanoates (PHA); biodegradable polyesters that are industrially applicable in bioplastics, biofuels, and medicine (Chen and Patel, 2012). The retinal proteins which participate in developing a variety of optical devices as photosensors are produced by halophilic archaea (haloarchaea) (Grote et al., 2014). In addition, Halotolerant microorganisms play an important role in food fermentation for manufacturing food and food supplements (Heldman et al., 2010). Successful bioremediation of oil spills has been observed in marine, Arctic, and Antarctic environments using heterotrophic, halophilic bacteria (Rezaei et al., 2018). Osmolytes are intracellular compatible solutes that preserve the metabolism of halophiles under salt stress (Burg and Ferraris, 2008). According to their chemical structure, they can be categorized into; polyols (glycerol, arabitol, mannitol, erythritol), sugars (sucrose, trehalose), betaines (trimethyl ammonium compounds), thetines (dimethylsulfonium compounds), amino acids (proline, glutamate, glutamine) and ectoines (ectoine, $\beta$-hydroxyectoine) (Lentzen and Schwarz 2006). Ectoine is considered a natural cyclic tetrahydropyrimidine with low molecular weight and great water-binding capacity. Ectoine maintains the integrity of proteins, DNA and enzymes inside haophilic cells upon exposing to different stresses. Thus, it has extensive applications in enzyme technology and pharmaceutical industry (Czech et al., 2018). In addition, ectoine is a very effective inhibitor for amyloid formation causing Alzheimer's disease and spongiform encephalopathies (Ashraf et al., 2014).

The objectives of this study are: (1) isolating new moderate halophiles from different hypersaline environments in Egypt; (2) investigating the type of compatible salts produced by isolated halophiles; (3) selecting the most-active ectoine producers; (4) characterizing the yielded ectoine by different chromatographic procedures.

\section{MATERIAL AND METHODS}

\section{Sampling}

Sixteen samples were collected from selected hypersaline environments including terrestrial and aquatic ecosystems; Abu kbeer, Ain Sokhna, Belbes, North coast, Port Said, Qaroun Lake and Wadi ElNatroun (Zug-Hamra \& El-Beida) during (June-October, 2015). Soil samples were kept in sterile plastic bags whereas seawater samples were collected using $500 \mathrm{ml}$ sterile labeled bottles; they were transported under cooling and aseptic conditions, and stored at $4^{\circ} \mathrm{C}$ until analysis. The $\mathrm{pH}$ and temperature were determined immediately after sampling process whereas the salt content of selected samples was estimated within two days. 


\section{Isolation of halophilic bacteria}

Five milliliters of each water samples or five grams of each soil sample were placed in $50 \mathrm{ml}$ sterile saline solution ( $0.9 \%$ ) and shaken for $1 \mathrm{~h}$ at 300 rpm. Ten-fold dilutions were made up to $10^{-7} ; 0.1 \mathrm{ml}$ of each dilution was plated on Synthetic agar medium as previously described (Hassan and Mahgoub, 2016). After incubation for $72 \mathrm{~h}$ at $30^{\circ} \mathrm{C}$, the number of growing halophiles was counted and expressed as Log of cell forming unit per gram. According to the morphological difference of growing halophiles; varied colonies were selected, purified and maintained for further studies.

\section{Identification of selected halophiles (The most active ectoine producer)}

Two bacterial isolates were selected out of sixty that showing a large ectoine production with a little by-product and identified by biochemical characterization and 16 s rRNA.

\section{Biochemical characterization of halophilic isolates}

The two selected halophilic isolates were stained with Gram's stain and examined by light-microscope to characterize their morphology and facilitate their identification using biochemical tests; Catalase activity, Citrate utilization, Gelatin hydrolysis, Hydrogen sulphide test, Indole production, Methyl Red/ Voges-Proskauer Test, Motility test, Oxidase test and Urease test as well as sugar fermentation (Azhar $\boldsymbol{e t}$ al., 2014).

The selected bacterial isolates were identified by sequence analysis of 16S RNA. Bacterial DNA was isolated from bacteria grown in Halophilic medium (HM) using the gene JET ${ }^{\mathrm{TM}}$ Genomic DNA Purification Kit (Fermentas, EU). PCR product was visualized by ethidium bromide using UV lamb transilluminator on $1 \%$ agarose gel and photographed using a digital camera (Sony). DNA amplification was carried out in $50 \mu 1$ PCR mixture containing $25 \mu 1$ Maxima Hot start PCR master mix (2x), $1 \mu \mathrm{M}$ of each primer, $5 \mu 1$ template DNA, $18 \mu 1$ water (nuclease free). PCR reaction was performed in Thermal cycler (Thermo ${ }^{\mathrm{TM}}$ ) using a pair of primer as following: forward: 5-AGA GTT TGA TCC TGG CTC AG-3, reverse 5,-GGT TAC CTT GTT ACG ACT T-3 (Wang and Wang, 1996). Each cycle started with an initial denaturation time $(5 \mathrm{~min})$ at $94^{\circ} \mathrm{C}$ followed by 35 cycles of amplification comprising a denaturation step for the $30 \mathrm{~s}$ at $94^{\circ} \mathrm{C}$, annealing at $65{ }^{\circ} \mathrm{C}$ for $1 \mathrm{~min}$, and extension at $72{ }^{\circ} \mathrm{C}$ for $1 \mathrm{~min}$ 30s. Reactions were completed with 10 min elongation at $72{ }^{\circ} \mathrm{C}$. The PCR product was purified using the gene JETTM PCR purification kit. Sequencing of the amplified DNA was performed by Solgent Co. Ltd (Seoul, South Korea) using automated sequence analyzer ABI 3730xl. The sequence was checked for correction by chimera system using pintail program and compared to standard alignments available at NCBI database http://www.ncbi.nlm.nih.gov/ BLAST. Then the phylogenetic tree was drawn using Mega-blast program version 6. The new nucleotide sequences were accessed in the GenBank under an accession number MK044835 and MK044836.

\section{ANALYTICAL PROCEDURES}

\section{Ectoine extraction}

Ectoine was extracted using two procedures according to purpose; solvent extraction (Ectoine quantification) and osmotic downshock (Ectoine purification). In the first procedure; growing cells were harvested by centrifugation $(6000 \mathrm{rpm})$ for $10 \mathrm{~min}$ and washed twice with $50 \mathrm{mM} \mathrm{Kpi} \mathrm{buffer} \mathrm{isotonic}$ to the medium. Harvested cells were suspended in $80 \%(\mathrm{~V} / \mathrm{V})$ ethanol and allowed to stand for $12 \mathrm{~h}$ to extract the intracellular compatible solutes. The intracellular extract was filtered and evaporated at $50^{\circ} \mathrm{C}$; the precipitate was re-suspended in a water/ chloroform $(1: 1 \mathrm{v} / \mathrm{v})$ mixture and mixed vigorously. The chloroform layer decanted and the upper clear layer was collected (Zhu et al., 2007). The second procedure is known as bacterial milking and based 
on exposing bacterial cells to different salinity systems (Sauer and Galinski, 1998). Due to osmotic shock, resting cells release ectoine to achieve osmotic equilibrium (Teixidó et al., 2005). This step is repeated to achieve maximum ectoine extraction before removing distorted cells and collecting the supernatant containing ectoine.

\section{Ectoine quantification}

Ectoine was determined by a high-performance liquid chromatography located at the Regional Center for Mycology and Biotechnology (Al-Azhar University, Cairo), using a C18 column and a mobile phase composed of acetonitrile and water (8:2) with $1 \mathrm{ml} / \mathrm{min}$ flow rate. Ectoine was detected at $210 \mathrm{~nm}$ and the concentration was calculated by the calibration curve constructed from the known concentrations of standard ectoine (Eshinimaev et al., 2007). In addition, ectoine was estimated indirectly by determining its hydrolysis products; N-alpha-Acetyldiaminobutyric acid (DABA) using a colorimetric reaction with ninhydrin. The crude ectoine dissolving in $1 \mathrm{ml} \mathrm{KOH}(0.1 \mathrm{M})$ is hydrolyzed for $20 \mathrm{~h}$ at $50^{\circ} \mathrm{C}$; the hydrolysis product reacts with $100 \mu \mathrm{l}$ ninhydrin ( $1 \%$ in absolute ethanol). Thereafter, this mixture was heated at $100^{\circ} \mathrm{C}$ in a water bath for 15 min, cooled at room temperature and its absorbance was estimated at $570 \mathrm{~nm}$ (Ono et al, 1998).

Concentration of ectoine $(\mathrm{mg} / \mathrm{ml})=\mathrm{O} \mathrm{D}_{570} / 0.054$

\section{Ectoine purification and characterization}

Protein decontaminated residues are removed from the crude ectoine solution by decreasing the $\mathrm{pH}$ to 1.4. The aqueous ectoine solution was purified using a Dowex $50 \mathrm{WX}_{8}$ cation exchange resin $\left(\mathrm{Na}^{+}\right.$ form) packed in a $1.4 \times 9 \mathrm{~cm}$ column. Ectoine was bound to the cation exchange resin where impurities were removed by washing with $\mathrm{HCl}(1.4 \mathrm{M})$. Subsequently, ectoine was eluted with $0.1 \mathrm{M} \mathrm{NaOH}$ and collected fractions were monitoring by UV-spectrophotometer until neutralization of eluted solution; the absorbance intensity of eluted fractions at 230 $\mathrm{nm}$ increased with increasing ectoine concentration. The partially purified fractions containing ectoine was lyophilized using a Modulyo ${ }^{\circledR}$ lyophilizer (Edwards, Sussex, England) and kept at $-4^{\circ} \mathrm{C}$ (Sauer and Galinski, 1998).

Ectoine dissolved in methanol was scanned by UV-Visible spectrophotometer in the range between $200 \mathrm{~nm}$ to $800 \mathrm{~nm}$ (Eshinimaev et al., 2007). The partially purified fractions containing ectoine was concentrated and loaded on glass plates coated with F60 silica gel that previously activated by heating for $105^{\circ} \mathrm{C}$ for $1 \mathrm{~h}$ (Vargas et al., 2006). Then, fractions were developed in a solvent system composed of n-butanol, water, and acetic acid in the ratio of (12: $5: 3 \mathrm{~V} / \mathrm{V} / \mathrm{V})$. The purified ectoine was detected by spraying the developing spots by $0.2 \%$ ninhydrin dissolved in ethanol and heating for $5 \mathrm{~min}$ at $130^{\circ} \mathrm{C}$. Finally, $\mathrm{R}_{\mathrm{f}}$ value of purified ectoine was determined in the reference of authentic ectoine purchased from Sigma Company (Ono et al., 1998).

In addition, ectoine was characterized by ${ }^{1} \mathrm{H}$ NMR, Mercury-300BB located at Micro Analytical Center, Faculty of Science, Cairo University using deuterated chloroform at $300 \mathrm{MHz}$. FT-IR analysis of ectoine was performed at Infrared lab, NCRRT, Egyptian atomic energy authority (A Bruker model Tensor 27 spectrometer, Bruker Corp., Billerica, MA) between 500 and $35000\left(\mathrm{~cm}^{-1}\right)$.

\section{Determination of other osmolytes}

The halophilic isolates were streaking on HM (Quillaguamán et al., 2004) and incubated at $30^{\circ} \mathrm{C}$ for $24 \mathrm{~h}$ Then, the production of polyhydroxyalkonates was estimated by $0.02 \%$ Sudan Black B in ethanol; the dark blue colour of colonies is a positive result (Gudmalwar and Kamble, 2014). In addition, the total carbohydrates derivatives and free amino acids contents were determined using the phenol-sulfuric acid method and Kjeldahl procedures; respectively (Dawson et al., 1986 and Reddy et al., 1983). 


\section{RESULTS}

\section{Physicochemical characteristics of various samples}

In the present study, sixteen samples were collected from hypersaline environments found in Egypt including terrestrial and aquatic ecosystems (Table 1). Water samples were collected from the Mediterranean Sea, Red Sea, Suez Canal and hypersaline lakes. In addition, five soil samples out of eight were selected from seawater sediments (beneath the water surface by $50 \mathrm{~cm}$ ) and two samples were collected from areas weren't previously planted due to high salinity content but they are nearby cultivated agricultural fields whereas only one sample represents saline mud. The data summarized in table (1) showed the physical characteristics of hypersaline environmental samples from different geographical regions in Egypt (Alexandria, El-Beheira, El-Sharkia, Matrouh, El-Fayoum, Port Said, El-Suez and South Sinai). Temperature and $\mathrm{pH}$ values of these samples are in a range of $31-39^{\circ} \mathrm{C}$ and $6.1-8.8$; respectively.

Table (1) : Physical characteristics of hypersaline environmental samples.

\begin{tabular}{|c|c|c|c|c|c|c|}
\hline \multirow{2}{*}{\multicolumn{2}{|c|}{$\begin{array}{l}\text { Sample } \\
\text { code }\end{array}$}} & \multirow{3}{*}{$\begin{array}{c}\text { Geographical location } \\
\text { Belbes- El-Sharkia }\end{array}$} & \multirow{3}{*}{$\begin{array}{c}\text { Sample type } \\
\text { Clay soil } \\
\end{array}$} & \multicolumn{3}{|c|}{ Physical characteristics } \\
\hline & & & & \multirow{2}{*}{$\begin{array}{c}\text { Color } \\
\text { Brownish Black }\end{array}$} & \multirow{2}{*}{$\frac{\mathrm{pH}}{6.1}$} & \multirow{2}{*}{$\frac{\operatorname{Temp}\left({ }^{\circ} \mathbf{C}\right)}{35}$} \\
\hline \multirow{8}{*}{ 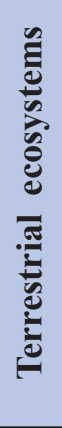 } & BS & & & & & \\
\hline & $\mathbf{C A}$ & North coast- Matrouh & Loamy soil & Brownish Black & 6.5 & 39 \\
\hline & CS & North coast- Matrouh & Sandy soil & Bright Creamy & 6.2 & 37 \\
\hline & $\mathbf{K S}$ & Abu kbeer- Ei-Sharkia & Sandy soil & Dark Yellow & 6.2 & 38 \\
\hline & PS & Port said- Port said & Saline mud & Dark Black & 6.3 & 30 \\
\hline & QS & Qaroun Lake- El-Fayoum & Sandy soil & Bright Golden & 6.3 & 38 \\
\hline & $\mathbf{R S}$ & Wadi El-Natroun- El-Beheira & Sandy soil & Brownish Black & 7.9 & 39 \\
\hline & $\mathbf{S}$ & Ain Sokhna-El-Suez & Sandy soil & Yellowish & 7.0 & 37 \\
\hline \multirow{8}{*}{ 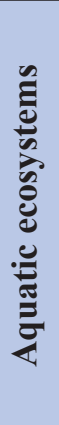 } & $\mathbf{A}$ & Alexandria & Seawater & Colorless & 6.3 & 31 \\
\hline & BW & Belbes- El-Sharkia & Well-water & Colorless & 6.3 & 35 \\
\hline & $\mathbf{C W}$ & North coast- Matrouh & Seawater & Colorless & 6.5 & 39 \\
\hline & $\mathbf{K W}$ & Abu kbeer- El-Sharkia & Seawater & Colorless & 6.3 & 38 \\
\hline & QW & Qaroun Lake- El-Fayoum & Seawater & Yellowish & 6.2 & 38 \\
\hline & RW & Wadi El-Natroun- El-Beheira & Lake water & Colorless & 8.8 & 39 \\
\hline & SH & Sharm El-Sheikh-South Sinai & Lake water & Colorless & 6.7 & 38 \\
\hline & $\mathbf{W}$ & Wadi El-Natroun- El-Beheira & Lake water & Colorless & 8.7 & 39 \\
\hline
\end{tabular}

Table (2) shows that the highest salinity contents of soil samples are observed in RS sample which was collected from sediments of Wadi El-Natroun lake (Zug-Hammra; Image 1a) whereas the lowest ones are estimated in BS sample. Analysis of PS sample (mud saline soil) reveals the highest value of calcium, magnesium, chloride, sulfate, sodium, and potassium ions. Similar to soil samples, the highest salinity content; $17.6 \%$ was estimated in water sample "W" collected from Wadi El-Natroun (El-Beida;
Image $1 \mathrm{~b}$ ) whereas the highest levels of chloride, carbonate, bicarbonate, sulfate, and sodium are measured in RW sample that also collected from Wadi El-Natroun lakes (Table 2). These concentrations are also higher than their comparable values in soil samples. The highest values of calcium and magnesium are estimated in samples A and $\mathrm{KW}$; respectively whereas the lowest values are found in RW and $\mathrm{SH}$ samples, on the same order. 
Table (2) : Chemical characteristics of soil sediment samples.

\begin{tabular}{|c|c|c|c|c|c|c|c|c|c|c|}
\hline \multirow{2}{*}{\multicolumn{2}{|c|}{$\begin{array}{c}\text { Sample } \\
\text { code }\end{array}$}} & \multirow{3}{*}{$\begin{array}{c}\text { Salinity } \\
\text { (\%) }\end{array}$} & \multicolumn{8}{|c|}{ Salt concentration (PPM) } \\
\hline & & & \multirow{2}{*}{$\frac{\mathbf{C a}^{+2}}{17.8}$} & \multirow{2}{*}{$\frac{\mathbf{M g}^{+2}}{11.0}$} & \multirow{2}{*}{$\frac{\mathbf{C l}^{-1}}{41.0}$} & \multirow{2}{*}{$\frac{\mathrm{CO}^{-2}{ }_{3}}{\text { N.D }}$} & \multirow{2}{*}{$\frac{\mathrm{HCO}_{3}^{-}}{6.0}$} & \multirow{2}{*}{$\frac{\mathrm{SO}_{4}^{-2}}{30.9}$} & \multirow{2}{*}{$\begin{array}{c}\mathbf{N a}^{+1} \\
58.0\end{array}$} & \multirow{2}{*}{$\frac{\mathbf{K}^{+1}}{0.7}$} \\
\hline \multirow{8}{*}{ 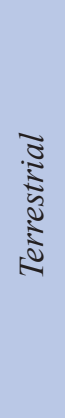 } & BS & & & & & & & & & \\
\hline & $\mathrm{CA}$ & 1.8 & 3.3 & 3.0 & 82.5 & N.D & 8.0 & 1.2 & 80.0 & 0.9 \\
\hline & $\mathrm{CS}$ & 3.1 & 2.6 & 4.5 & 80.0 & N.D & 5.0 & 0.9 & 82.0 & 1.1 \\
\hline & KS & 2.9 & 2.2 & 6.5 & 92.0 & N.D & 5.5 & 7.1 & 110.0 & 1.3 \\
\hline & PS & 13.2 & 24.7 & 11.3 & 425.0 & N.D & 5.0 & 121.5 & 225.0 & 2.5 \\
\hline & QS & 3.6 & 2.8 & 4.9 & 111.0 & N.D & 6.5 & 0.51 & 122.0 & 1.4 \\
\hline & RS & 6.4 & 3.2 & 3.8 & 151.0 & 3.0 & 12.5 & 0.24 & 132.0 & 1.5 \\
\hline & $S$ & 2.3 & 2.9 & 6.4 & 128.0 & N.D & 8.5 & 0.14 & 111.0 & 1.3 \\
\hline \multirow{8}{*}{$\frac{\pi}{3}$} & $\mathrm{~A}$ & 5.2 & 17.6 & 11.2 & 125.0 & 3.5 & 71.3 & 11.2 & 120.0 & 1.5 \\
\hline & BW & 0.13 & 3.6 & 3.9 & 8.0 & 0.6 & 0.02 & 3.9 & 6.1 & 0.2 \\
\hline & $\mathrm{CW}$ & 5.9 & 17.4 & 0.43 & 127.0 & N.D & 73.5 & 0.43 & 110.0 & 1.4 \\
\hline & KW & 6.1 & 16.9 & 12.9 & 135.0 & N.D & 68.7 & 12.9 & 130.0 & 1.9 \\
\hline & QW & 3.7 & 15.9 & 7.9 & 98.0 & N.D & 207.7 & 7.9 & 100.0 & 1.7 \\
\hline & RW & 16.1 & 0.05 & 3.0 & 276.0 & 330.0 & 708.7 & 3.0 & 150.0 & 2.9 \\
\hline & SH & 4.8 & 16.7 & 0.35 & 144.0 & 4.2 & 72.5 & 0.35 & 128.0 & 1.7 \\
\hline & $\mathrm{W}$ & 17.6 & 1.3 & 2.5 & 269.0 & 240.0 & 711.0 & 2.5 & 146.0 & 2.5 \\
\hline
\end{tabular}

*N.D: Not Detected

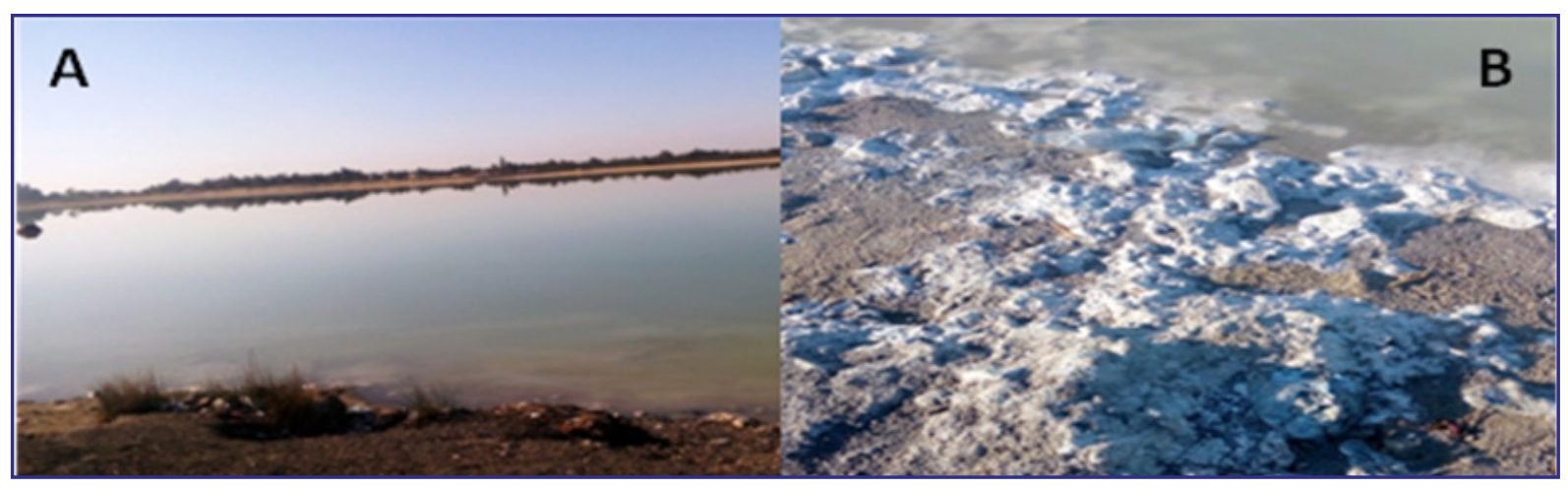

Image 1: Photo of hypersaline environmental samples

A: Zug-Hammra, Wadi El-Natroun

\section{Isolation of moderately halophilic bacteria from terrestrial and aquatic ecosystems}

Isolation of halophilic bacteria from their natural habitats requires adaptation process before they are able to grow on synthetic media with high salt concentration (10\%). Table (3) shows the viability of moderately halophilic bacteria in selected samples on synthetic medium at $30^{\circ} \mathrm{C}$. RS sample that was
B: El-Beida, Wadi El-Natroun

collected from soil salt marsh from Wadi El-Natroun shows the highest total bacterial count; $6.4 \times 10^{4}$ CFU/g ( $\log \mathrm{N}: 4.81)$ whereas the lowest total bacteria count ( $\log \mathrm{N}$ : 1.79) was isolated from PS sample that has the highest chloride concentration as shown in table (2). Thirty-four bacterial isolates were selected from soil samples according to their morphological difference, purified and preserved on LB me- 
dium at $4{ }^{\circ} \mathrm{C}$. These bacterial isolates were symbolized referring to their origin (soil samples) as shown in table (3). Regarding aquatic ecosystem, twentysix bacterial isolates were also selected purified and preserved on Luria-Bertani medium (Hassan and
Mahgoub, 2016) at $4^{\circ} \mathrm{C}$. The maximum halophiles count was observed in RW sample; $4.8 \times 10^{4}(\mathrm{CFU} /$ $\mathrm{ml}$ ) that are collected from Zug-Hammra (Wadi ElNatroun Lake) whereas the lowest halophile count was showed in "A sample" $\left(2.2 \times 10^{2} \mathrm{CFU} / \mathrm{ml}\right)$.

Table (3) : Isolation of moderately halophilic bacteria from terrestrial and aquatic ecosystems.

\begin{tabular}{|c|c|c|c|c|c|}
\hline \multirow{2}{*}{\multicolumn{2}{|c|}{$\begin{array}{c}\text { Sample } \\
\text { code }\end{array}$}} & \multicolumn{2}{|c|}{ Total bacterial count } & \multirow{3}{*}{$\begin{array}{c}\begin{array}{c}\text { No of isolated } \\
\text { halophiles* }\end{array} \\
1 \\
\end{array}$} & \multirow{3}{*}{$\begin{array}{c}\text { Symbol of selected halophiles } \\
\mathrm{BS}_{1} \\
\end{array}$} \\
\hline & & \multirow{2}{*}{$\begin{array}{c}\mathbf{C F U} / \mathrm{g} \\
4.4 \times 10^{2} \\
\end{array}$} & \multirow{2}{*}{$\frac{\log \mathbf{N}}{2.64}$} & & \\
\hline \multirow{8}{*}{ 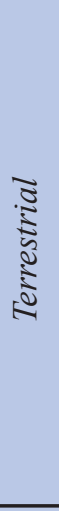 } & BS & & & & \\
\hline & $\mathrm{CA}$ & $5.0 \times 10^{4}$ & 3.70 & 10 & $\begin{array}{c}\mathrm{CA}_{1}, \mathrm{CA}_{2}, \mathrm{CA}_{3}, \mathrm{CA}_{4}, \mathrm{CA}_{5}, \mathrm{CA}_{6}, \mathrm{CA}_{7}, \\
\mathrm{CA}_{8}, \mathrm{CA}_{9}, \mathrm{CA}_{10}\end{array}$ \\
\hline & $\mathrm{CS}$ & $4.2 \times 10^{3}$ & 3.62 & 6 & $\mathrm{CS}_{1}, \mathrm{CS}_{2}, \mathrm{CS}_{3}, \mathrm{CS}_{4}, \mathrm{CS}_{5}, \mathrm{CS}_{6}$ \\
\hline & KS & $2.1 \times 10^{4}$ & 4.32 & 2 & $\mathrm{KS}_{1}, \mathrm{KS}_{2}$ \\
\hline & PS & $6.2 \times 10$ & 1.79 & 3 & $\mathrm{PS}_{1}, \mathrm{PS}_{2}, \mathrm{PS}_{3}$ \\
\hline & QS & $5.3 \times 10^{2}$ & 2.72 & 2 & $\mathrm{QS}_{1}, \mathrm{QS}_{2}$ \\
\hline & RS & $6.4 \times 10^{4}$ & 4.81 & 6 & $\mathrm{RS}_{1}, \mathrm{RS}_{2}, \mathrm{RS}_{3}, \mathrm{RS}_{4}, \mathrm{RS}_{5}, \mathrm{RS}_{6}$ \\
\hline & $\mathrm{S}$ & $3.5 \times 10^{3}$ & 3.54 & 4 & $\mathrm{~S}_{1}, \mathrm{~S}_{2}, \mathrm{~S}_{3}, \mathrm{~S}_{4}$ \\
\hline \multirow{8}{*}{$\frac{\pi}{3}$} & A & $2.2 \times 10^{2}$ & 2.34 & 2 & $\mathrm{~A}_{1}, \mathrm{~A}_{2}$ \\
\hline & BW & $4.5 \times 10^{2}$ & 2.65 & 2 & $\mathrm{BW}_{1}, \mathrm{BW}_{2}$ \\
\hline & $\mathrm{CW}$ & $2.5 \times 10^{4}$ & 4.40 & 4 & $\mathrm{CW}_{1}, \mathrm{CW}_{2}, \mathrm{CW}_{3}, \mathrm{CW}_{4}$ \\
\hline & KW & $1.5 \times 10^{4}$ & 4.18 & 2 & $\mathrm{KW}_{1}, \mathrm{KW}_{2}$ \\
\hline & QW & $4.3 \times 10^{3}$ & 3.63 & 2 & $\mathrm{QW}_{1}, \mathrm{QW}_{2}$ \\
\hline & RW & $4.8 \times 10^{4}$ & 4.68 & 6 & $\mathrm{RW}_{1}, \mathrm{RW}_{2}, \mathrm{RW}_{3}, \mathrm{RW}_{4}, \mathrm{RW}_{5}, \mathrm{RW}_{6}$ \\
\hline & $\mathrm{SH}$ & $2.5 \times 10^{4}$ & 4.40 & 4 & $\mathrm{SH}_{1}, \mathrm{SH}_{2}, \mathrm{SH}_{3}, \mathrm{SH}_{4}$ \\
\hline & $\mathrm{W}$ & $4.0 \times 10^{4}$ & 4.60 & 4 & $\mathrm{~W}_{1}, \mathrm{~W}_{2}, \mathrm{~W}_{3}, \mathrm{~W}_{4}$ \\
\hline
\end{tabular}

* According to morphological characteristics

\section{Screening the most potent selected isolates for ectoine production}

A total of 60 halophilic isolates (selected during June-October 2015) were screened for ectoine production. In a preliminary experiment, the intracellular extracts of these isolates after growing on $\mathrm{HM}$ medium supplemented with $10 \% \mathrm{NaCl}$ at $30^{\circ} \mathrm{C}$ for $72 \mathrm{~h}$ under shaking conditions (150 rpm) were analyzed chromatographically using a thin layer. Ectoine-production is cleared as violet-red spots with $0.3 \mathrm{R}_{\mathrm{f}}$ value; this $\mathrm{R}_{\mathrm{f}}$ is comparable to standard ectoine (plate 1). Results revealed 15 bacterial isolates out of 60 could produce ectoine as compatible solute. HPLC studies (Table 4) revealed the superiority of a moderate halophilic isolate (CS1) that selected from saline soil of the North Coast of Egypt (Matrouh governorate) in ectoine production (28.62 $\mathrm{mg} / \mathrm{g}$ ) followed by SH3 which isolated from a water sample of Red sea $(27.83 \mathrm{mg} / \mathrm{g})$ whereas the lowest ectoine yields were estimated by BW2, CA1 and CA9 halophiles (less than $15 \mathrm{mg} / \mathrm{g}$ ). 


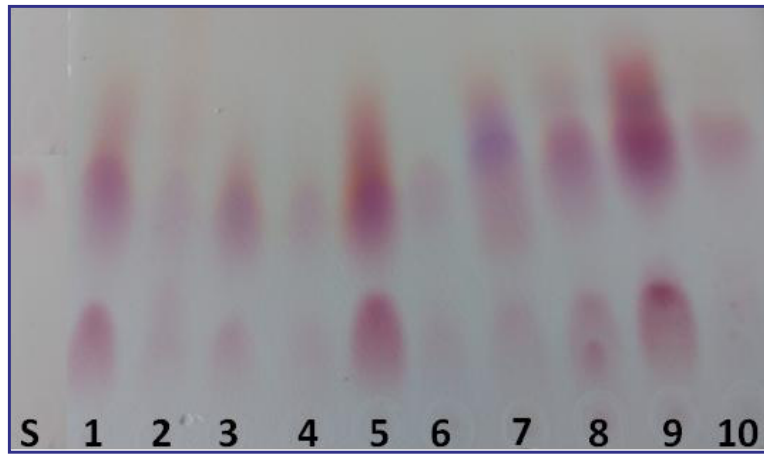

Plate 1: TLC plate showing ectoine as violet-red spots with Rf value 0.3

S: Standard ectoine

1-10: Intracellular extracts of selected halophiles

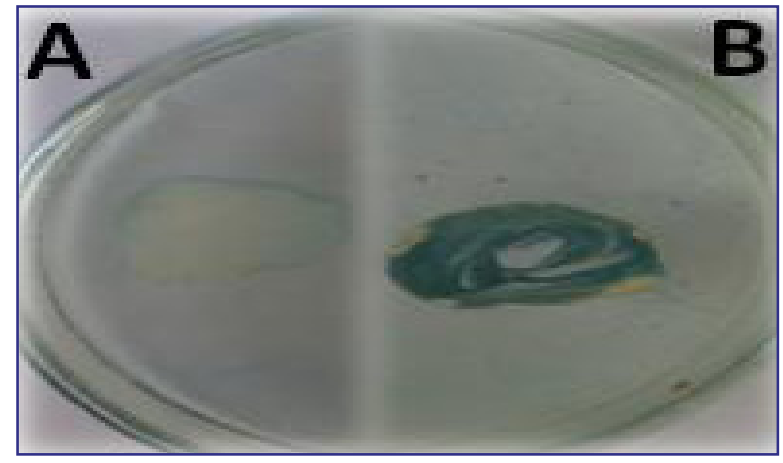

Plate 2: Estimation of PHA production using Sudan black stain

A: -ve PHA production

B: +ve PHA production

Table (4) : Screening of selected halophilic bacteria for compatible salts production.

\begin{tabular}{|c|c|c|c|c|}
\hline \multirow{2}{*}{$\begin{array}{c}\text { Symbol of Selected } \\
\text { halophiles }\end{array}$} & \multirow{2}{*}{$\begin{array}{c}\text { Ectoine yield } \\
(\mathbf{m g} / \mathbf{g})\end{array}$} & $\begin{array}{c}|c| \\
\text { Polyhydroxy } \\
\text { Alkonate (PHA) }\end{array}$ & $\begin{array}{c}\text { Carbohydrate } \\
\text { derivatives (mg/g) }\end{array}$ & $\begin{array}{c}\text { Free amino acids } \\
\text { derivatives (mg/g) }\end{array}$ \\
\hline BW1 & 17.10 & - & 1.22 & 3.28 \\
\hline BW2 & 10.88 & - & 5.00 & 1.94 \\
\hline CA1 & 11.92 & - & 3.48 & 27.06 \\
\hline CA2 & 20.89 & + & 3.42 & 17.63 \\
\hline CA5 & 22.35 & - & 3.82 & 4.75 \\
\hline CA9 & 13.33 & + & 1.93 & 5.04 \\
\hline CS1 & 28.62 & - & 4.25 & 1.10 \\
\hline CS2 & 17.85 & + & 1.70 & 9.55 \\
\hline CS5 & 19.64 & + & 4.30 & 39.06 \\
\hline CS6 & 23.92 & - & 3.27 & 2.52 \\
\hline CW1 & 15.74 & + & 5.44 & 71.63 \\
\hline KW2 & 24.00 & - & 12.31 & 64.20 \\
\hline QW2 & 22.93 & - & 3.39 & 15.22 \\
\hline S2 & 17.27 & + & 5.14 & 20.59 \\
\hline SH3 & 27.82 & - & 3.72 & 6.28 \\
\hline
\end{tabular}

To choose the best candidate for ectoine production in the industrial point of view, the present study assumed a strategy based on selecting ectoine with minimum amounts of by-products or without by-products at all. It's known that moderate halophilic bacteria can accumulate sugars, Polyhydroxy Alkonate (PHA) and free amino acids under stress conditions as compatible solutes. The selected halo- philes (15 bacterial isolates) were tested for PHA production; results showed six bacterial isolates (CA2, CA9, CS2, CS5, CW1, and S2) were able to produce PHA (Table 4). Plate (2) showed the positive result of PHA production as estimated by Sudan black stain. In addition, the yield of osmolytes with sugar-origin is ranged between $1.22 \mathrm{mg} / \mathrm{g}$ (BW1) and $12.31 \mathrm{mg} / \mathrm{g}$ (KW2) as shown in table (4). The 
contamination of ectoine with amino acids derivatives is another technical problem facing the industrial production of ectoine by halophiles. Table (4) also shows the free amino acid content is ranged between $1.10 \mathrm{mg} / \mathrm{g}(\mathrm{CS} 1)$ and $71.63 \mathrm{mg} / \mathrm{g}$ (CW1).

\section{Identification of the most active ectoine producers}

\section{Molecular identification of the most active ectoine producers}

The polymerase chain reaction (PCR) is a powerful tool for identifying bacteria and commonly used to amplify 16S rRNA genes (Yeung et al., 2009). According to the results, the $16 \mathrm{~S}$ rRNA gene of the most active ectoine producers CS1 and SH3 were amplified successfully with $1.5 \mathrm{~kb}$ band size (Image 2). The PCR products were sent to Solgent Co. Ltd (Seoul, South Korea) for purification and seK quencing using automated sequence analyzer.

The result sequences 1166 and 1051 bp for selected halophiles CS1 and SH3; respectively were assembled with genomes available at NCBI database (www.ncbi.nlm.nih.gov).

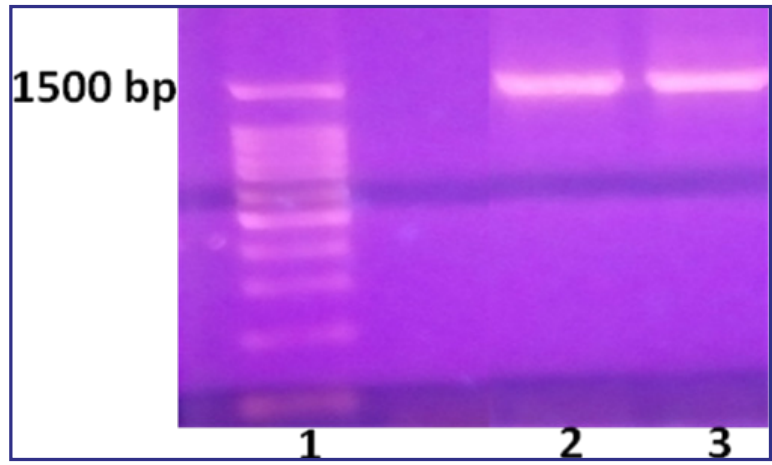

Image (2): Agarose gel electrophoresis for PCR products of amplified 16S rRNA (approximately $1.5 \mathrm{kbp}$ )

Lane (1): DNA molecular weight marker (1 kb)

Lane (2): Amplified PCR products of Vibrio sp. CS1

Lane (3): Amplified PCR products of Salinivibrio costicola $\mathrm{SH} 3$

The 16S rRNA sequencing proved the high similarity of selected halophiles CS1 (97\%) with Vibrio sp. Q09 (accession number KY818842.1) and of SH3 (99\%) with Salinivibrio costicola pb-WC11147 (accession number JX913853.1). Figure (1) clears the phylogenetic trees of selected halophiles using blast program; the new sequences were registered at NCBI with accession numbers MK044835 and MK044836 on the same order.

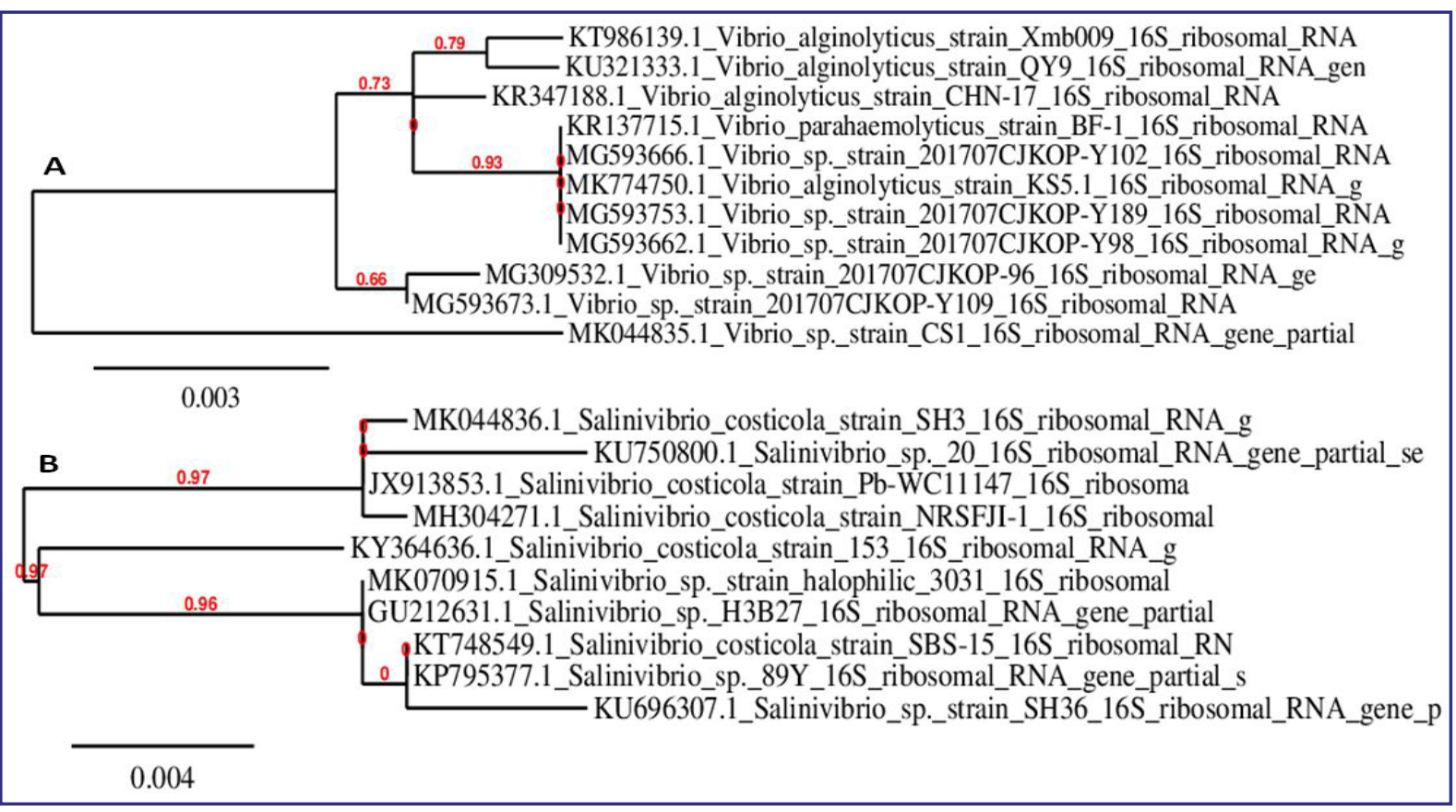

Figure (1): Neighbour-joining phylogenetic trees of selected halophiles $\begin{array}{ll}\text { (A) Vibrio sp. CS1 } & \text { (B) Salinivibrio costicola SH3. }\end{array}$ 


\section{Physiological characterization and biochemical features most active ectoine producers}

Phenotype methods are classical methods used in laboratories for classification and identification of microorganisms based on their morphological and biochemical characterization (Donelli et al., 2013). Colonies of CS1 (Vibrio sp.) are flat, circular with smooth margins and has no reverse pigmentation. It is gram-negative, non-motile short rod with moderate salinity tolerant $(15 \%)$ but it can't grow in the absence of $\mathrm{NaCl}$. It has the ability to grow in a wide range of temperature $\left(15-40^{\circ} \mathrm{C}\right)$ and $\mathrm{pH}$ values $(5.5$ 10.0). It also shows positive results with catalase, gelatin liquefication, methyl red, and citrate utilization and negative results with oxidase, urease, indole and hydrogen sulfide production and Vogas-Proskaeur (Table 5).

Regarding SH3 (Salinivibrio costicola); it is convex, circular and creamy in color as well as motile, rod-shaped and gram-negative bacteria. It able to grow under a wide range of $\mathrm{NaCl}(0.5$ to $20 \%)$ and can't grow in the absence of $\mathrm{NaCl}$. It has the ability to grow in a wide range of temperature degrees $\left(15-50^{\circ} \mathrm{C}\right)$ and it grows better under alkaline conditions (5.5-10.0). It is positive for catalase and gelatin liquefaction and negative for oxidase test, urea, and $\mathrm{H}_{2} \mathrm{~S}$ production. IMVIC test showed that it is positive for indole production, Vogas-Proskaeur and citrate utilization while negative for methyl-red (Table 5).

Table (5) : Screening of selected halophilic bacteria for compatible salts production.

\begin{tabular}{|c|c|c|}
\hline Characteristic features & Vibrio sp.CS1 & S. costicola SH3 \\
\hline Gram-Stain & Negative & Negative \\
\hline Cell morphology & Short rod & Short rod \\
\hline Cell pigmentation & Creamy & Creamy \\
\hline Motility & Non- motile & Motile \\
\hline NaCl tolerance (\%) & $0.5-15$ & $0.5-20$ \\
\hline pH tolerance & $5.5-10.0$ & $5.5-10.0$ \\
\hline Temperature tolerance ( ${ }^{\text {C) }}$ & $15-40$ & $15-50$ \\
\hline Catalase test & + & + \\
\hline Citrate utilization & + & + \\
\hline Gelatin hydrolysis & + & + \\
\hline H S production & - & - \\
\hline Indole production & - & + \\
\hline Methyl red test & + & - \\
\hline Oxidase test & - & + \\
\hline Voges-Proskaeur test & - & - \\
\hline Urease test & - & + \\
\hline Sugar fermentation & + & + \\
\hline Galactose & + & + \\
\hline Glucose & + & + \\
\hline Lactose & + & + \\
\hline Mannitol & + & + \\
\hline Mannose & + & + \\
\hline Melibiose & + & + \\
\hline Sucrose & + & + \\
\hline
\end{tabular}


In addition, the fermentation abilities of selected halophiles were examined for different sugar substrates (galactose, glucose, lactose, mannitol, mannose, melibiose and sucrose). Table (5) shows the positive fermentation ability (acid and gas production) of Vibrio sp. CS1 for galactose, glucose, mannitol, mannose, and sucrose and negative fermentation ability for lactose and melibiose. Regarding Salinivibrio costicola SH3, it shows fermentation ability for glucose, mannitol, mannose, and sucrose only.

\section{Purification of ectoine}

The acidified concentrated crude ectoine was eluted with $\mathrm{HCl}$ solution ( $\mathrm{pH}$ 1.4) to remove the uncharged and negatively charged compounds. Afterward, purified ectoine was eluted with $0.1 \mathrm{M} \mathrm{NaOH}$. Twelve fractions were collected from the elution and the collection process was stopped when the $\mathrm{pH}$ of the solution reached neutral. Ectoine fractions were monitored by UV-Visible spectroscopy at $(230 \mathrm{~nm})$. Screening process revealed the absence of ectoine from the first nine fractions and the other fractions that showed a clear absorbance at $230 \mathrm{~nm}$ were stored for ectoine characterization.

\section{Characterization of ectoine}

Physical description of purified ectoine (after cation exchange chromatography) is completely different from the crude one that released from cells of selected halophiles (Vibrio sp. CS1 and Salinivibrio costicola SH3). Crude ectoine is a massive cake containing large percent of $\mathrm{NaCl}$ whereas purified one has a colorless fine needle crystal shape. The solubility of ectoine in different organic solvents; acetone, chloroform, absolute ethanol, isopropyl alcohol, methanol, n-heptane, toluene as well as water were examined. Results revealed the high solubility of ectoine in water, followed by methanol and finally ethanol and isopropyl alcohol. In addition, it is insoluble in acetone, chloroform, n-heptane, and toluene. Thus, organic solvents as ethanol and methanol can- not be used individually for extracting ectoine but the mixture of water and ethanol or methanol is more effective.

The absorbance spectrum of purified ectoine was examined using UV-Visible spectrophotometer (200- $1000 \mathrm{~nm}$ ). The spectrum of ectoine dissolved in methanol showed that there is only one strong peak observed at the ultra-violet region and the absorption spectrum starts at $195 \mathrm{~nm}$ and ends at 230 $\mathrm{nm}$ with maximum intensity at $208 \mathrm{~nm}$ (Fig. 2). ${ }^{1} \mathrm{H}$ NMR is a rapid method for analyzing and identification of ectoine. In the present study, purified ectoine was analyzed by ${ }^{1} \mathrm{H}$ NMR using $\mathrm{D}_{2} \mathrm{O}$ as a mobile solvent. ${ }^{1} \mathrm{H}-\mathrm{NMR}$ spectrum shows the hydrogen atoms peaks of purified ectoine is the same as the analogue of authentic one (purity $>99 \%$ ) at 2-5 ppm (Figure 3 ). The purified ectoine and authentic ectoine were scanned using Fourier transform infrared spectroscopy (FTIR), between 500 and $35000 \quad\left(\mathrm{~cm}^{-1}\right)$. Figure (4) shows a similar fingerprint between the bacterial ectoine and authentic one.

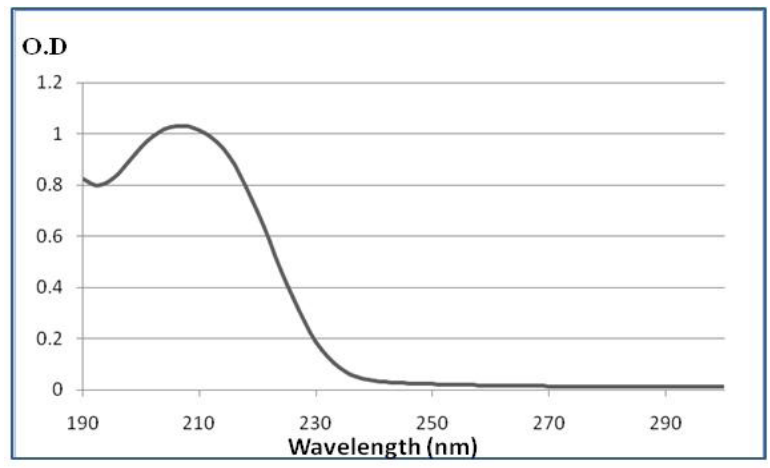

Figure (2): UV-spectrum of ectoine dissolved in methanol.

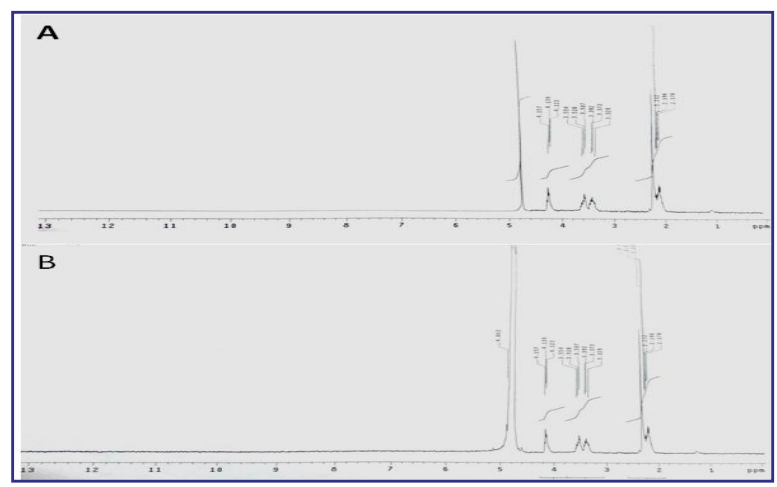

Figure (3): ${ }^{1} \mathrm{H}$-NMR spectrums A: Authentic Ectoine and B: Purified Ectoine. 


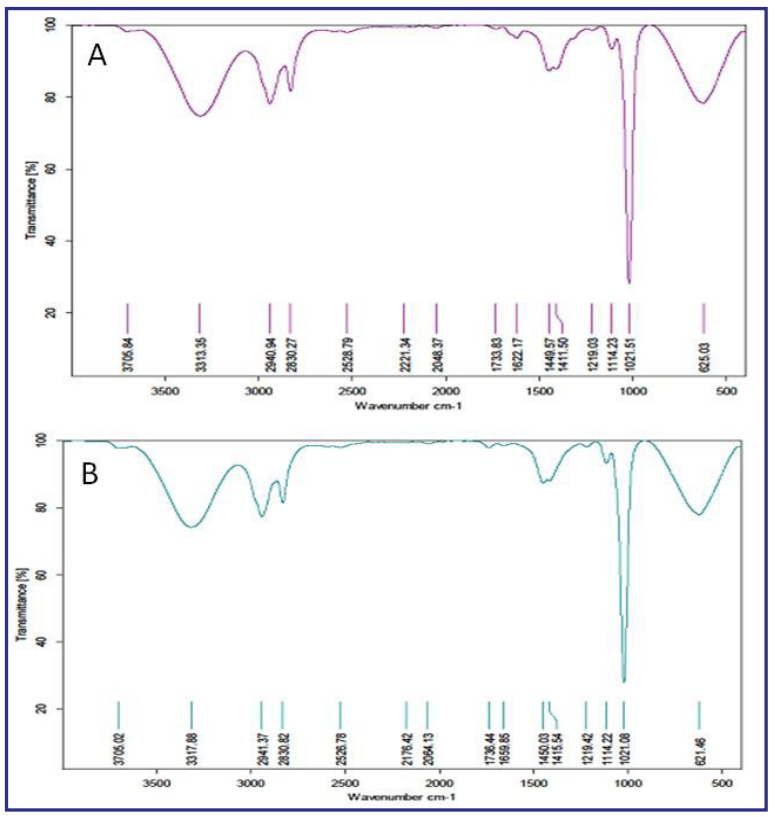

Figure (4): FTIR spectrums A: Authentic Ectoine B: Purified Ectoine.

\section{DISCUSSION}

Hypersaline environments with high salinity comprising soil and water are widespread all over the world. Oceans are the largest hypersaline environments constituting approximately $72 \%$ of the biosphere and contain more than $3.5 \%$ total dissolved salts. The salinity system of seawater depends on the concentrations of dissolved salts including $\mathrm{Na}^{+}, \mathrm{Cl}^{-}$, $\mathrm{SO}_{4}^{-2}, \mathrm{Mg}^{+2}, \mathrm{Ca}^{+2}$, and $\mathrm{K}^{+}$that varied by a balance between evaporation and precipitation (Nessim et al., 2015). In addition, the salinity of hypersaline lakes is seasonally varied; it is increased in summer by evaporation and decreased in winter due to rainfalls. The salinity system in Wadi El-Natroun is distinctive to the other salinity ecosystems prevalent in Egypt especially their physical properties and chemical composition. Taher (1999) determined the salinity of Wadi El-Natroun lakes is ranged from 283 to 540 $\mathrm{g} / \mathrm{l}$. In addition, Hydrogen ion concentration $(\mathrm{pH}-$ value) of Wadi El-Natroun samples is alkaline due to the presence of a high concentration of carbonate whereas $\mathrm{pH}$ values of various salinity ecosystems in Egypt are almost neutral (Abdelmongy and ElMoselhy, 2015).
The present study succeeds to isolate 60 halophilic bacteria from biodiversity ecosystems in Egypt either terrestrial or aquatic environment. On the same trend, Osman et al., (2009) isolated halophilic bacteria Halomonas sp. EG6 from Burg ElArab Lake, Egypt. That strain was tolerant to high $\mathrm{NaCl}$ concentration up to $4 \mathrm{M}$ and able to synthesis ectoine as the main compatible solute with moderate productivity; $3.7 \mathrm{~g} / 1$ after 7 days of osmotic downshock. Elbanna et al., (2015) selected Halobacterium sp. HP25 out of 33 halophilic bacterial isolates from Qarun Lake, Egypt. Its growth yield, as well as protease production, was maximized at $30 \% \mathrm{NaCl}(\mathrm{W} / \mathrm{V})$. Nada et al., (2011) isolated onehundred bacteria from different saline soils of Wadi El-Natroun, the North coast, Giza and El-Sharqia governorates. These isolates belonged to Halococcus salifodinae, Pseudomonas aeruginosa, Pseudomonas frourescens, and Pseudomonas mallei. Out of them, four isolates are salt-tolerance due to the expression of EctC gene that responsible for ectoine production. Alternatively, thalassohaline hypersaline environments; saltern pond as Wadi El-Natroun lake may include communities survive salinity up to $30 \%$ with dominance to Acinetobacter, Alcaligenes, Alteromonas, Flavobacterium, Pseudomonas, and Salinivibrio (Ventosa et al., 1998)

Ectoine is one of the compatible solutes that synthesized by different types of bacteria in hypertonic environments to overcome osmotic stress (Gao et al., 2014). The present study aims to select local halophilic isolates having ectoine as the predominant compatible solute. Thin layer chromatography shows $25 \%$ of selected halophiles synthesize ectoine with $\mathrm{R}_{\mathrm{f}}$ equals 0.3 . Similarly, Vaidya et al., (2018) identified ectoine in halophilic bacterial strains; Halobacillus trueperi SS1 and Halobacillus trueperi SS3 using TLC as orange-red spots with 0.32 $\mathrm{R}_{\mathrm{f}}$ value. Selected ectoine producers are belonging to Vibrio and Salinivibrio genera, the latter genus is constructed for differentiating between Salinivibrio costicola and Vibrio species. Salinivibrio costicola 
is facultative anaerobic Gram-negative bacteria and haloalkaliphilic as well as motile and non-sporeformer. Salinivibrio costicola BAG strain isolated from a saline lake in Ras Mohammed (Egypt) grew optimally at $35^{\circ} \mathrm{C}$ with salinity tolerance up to $16 \%$ and it is tolerant to $\mathrm{pH}$ values between 6.0 and 10.0 (Romano et al., 2011).

The accumulation of different osmolytes inside bacterial cells depends on the type of species and growth conditions (Joghee and Jayaraman, 2016). Mothes et al., (2008) found that Halomonas elongata simultaneously synthesized PHA and ectoine under stress conditions during shortage of nutrients and high osmotic pressure. After three days of incubation, their yields were $50 \%$ and $14 \%$; respectively at $10 \% \mathrm{NaCl}$. Van-Thuoc et al. (2010) studied the coproduction of ectoine and biopolyester poly (3-hydroxybutyrate) (PHB) by Halomonas boliviensis in two fed-batch cultures. In the first stage, high cell mass was achieved whereas high yields of ectoine and PHB were maximized in the second stage. At $7.5 \% \mathrm{NaCl}, \mathrm{PHB}$ and ectoine contents represented $68.5 \%$ and $7.2 \%$. With higher $\mathrm{NaCl}$ concentration $(12.5 \%)$, the ectoine content increased up to $17 \%$. However, the yield of ectoine in this co-production process isn't cost-effectiveness (Chen et al., 2014). Alternatively, in the present study, the isolated halophiles having the ability to produce PHA are excluded during the selection process. Carbohydrate, sugars and their derivatives as trehalose, sucrose, glycerol, and arabitol play a role as compatible solutes in halotolerant bacteria especially trehalose that used as a cryoprotectant for freeze-drying of bio-molecules (Margesin and Schinner, 2001). It's found that Halorhodospira halochloris accumulated three compatible solutes; glycine betaine, trehalose, and ectoine; the latter solutes were synthesized under carbon limitation while the former one under nitrogen shortage (Roberts, 2005).

Selecting candidates synthesize ectoine with low amino acid derivatives is the final step in screening process. Oren (2006) found that Halomonas elongata produce $\mathrm{K}^{+}$glutamate as the major compatible solute at $3 \% \mathrm{NaCl}$ or less whereas, at higher salinities, ectoine is the predominant compatible solute. On the same trend, it is mentioned that Virgibacillus pantothenticus; the Gram-positive bacteria requires pantothenic acid for growth; synthesized the compatible solutes proline and ectoine under salt stress. The moderate salinity stress was accompanied by rising in proline concentration whereas ectoine was dominated at higher regimes. This phenomenon has termed as "osmolyte switching" (Kuhlmann et al., 2011).

In the present study, purification of ectoine was based on cation exchange chromatography using appreciate resin (negatively charged polymer) in which act as a medium for positive ion exchange (Shivanand and Mugeraya, 2011). Crude ectoine was acidified with concentrated $\mathrm{HCl}$ to convert zwitterionic ectoine $(\mathrm{pH} 7)$ to cationic form $(\mathrm{pH} \mathrm{1.4)} \mathrm{as}$ well as to remove protein residues and solid impurities (Rui-Feng et al., 2017). Onraedt et al., (2005) mentioned that the purification process of ectoine depends on the difference between the solubility of $\mathrm{NaCl}$ and ectoine in $80 \%$ ethanol since $\mathrm{NaCl}$ exists with crude ectoine as a contaminant. NMR spectroscopy is a powerful technique for identifying the chemical molecular structure of various natural-origin compounds in which the atomic nuclei of any biomolecule can be oriented in the presence of a strong magnetic field with characteristic frequencies (Motta et al., 2004). According to previous reviews, peaks at $2.17-2.20$ ppm arise from $\mathrm{H}_{3}$ and $\mathrm{H}_{6}$; respectively whereas peaks at $3.3-3.5 \mathrm{ppm}$ and 4.1 ppm represent $\mathrm{H}_{4}$ and $\mathrm{H}_{2}$ on the same order. Methyl group linked to pyrimidine range frequently appears at $2.5 \mathrm{ppm}$ (Kondepudi and Chandra, 2011). Ongagna-Yhombi and Boyd (2013) also examined the production of ectoine and glutamate as osmolytes by Vibrio parahaemolyticus in response to different salinity stress $(1,3$ and $6 \% \mathrm{NaCl})$ using ${ }^{1} \mathrm{H} \mathrm{NMR}$. 
No peaks for compatible solutes were detected in the spectrum at $1 \% \mathrm{NaCl}$ where proton peaks of other metabolic products are predominant. On the other hand, peaks of glutamate and ectoine were detected at 3 and $6 \% \mathrm{NaCl}$, and the intensity and size of ectoine peak are increased over glutamate as increasing $\mathrm{NaCl}$ concentrations. Alternatively, Tanne et al., (2014) differentiate between ectoine and hydroxyectoine using FTIR spectrometer. Both spectra contain broad overlapping bands in the hydrogen stretching region $\mathrm{N}-\mathrm{H}, \mathrm{C}-\mathrm{H}$ and $\mathrm{N}-\mathrm{H}\left(>2500 \mathrm{~cm}^{-1}\right)$. The fingerprint of hydroxyectoine clears its richness by $\mathrm{OH}$ that attached to heterocyclic ring thus the bands at $1088 \mathrm{~cm}^{-1}$ does not exist in the ectoine spectrum.

In conclusion, isolating industrial candidates from new environmental resources acts as a potent strategy for selecting microbial strains with higher metabolites yield. Thus, the present study succeeds to select bacterial strains with potent ectoine productivity and a lower content of other osmolytes whatever their nature, polyhyhroxy alkonate free amino acids or polysaccharides.

\section{REFERENCES}

- Abdelmongy, A. and El-Moselhy, K. (2015): Seasonal Variations of the Physical and Chemical Properties of Seawater at the Northern Red Sea, Egypt. Open J. Ocean Coast. Sci., 2 (1): 1.

- $\quad$ Ashraf, G.M.; Greig, N.H.; Khan, T.A.; Hassan, I.; Tabrez, S.; Shakil, S.; Sheikh, I.A.; Zaidi, S.K.; Wali, M.A.; Jabir, N.R.; Firoz, C.K.; Naeem, A.; Alhazza, I.M.; Damanhouri, G.A. and Kamal, M.A. (2014). Protein misfolding and aggregation in Alzheimer's disease and Type 2 Diabetes Mellitus. CNS Neurol. Disord. Drug Targets, 13 (7): 1280.

- Azhar, M.; Uniyal, V.; Chauhan, N. and Rawat, D.S. (2014): Isolation and biochemical characterization of Halophiles from Sahastradhara region, Dehradun, India. Int. J. Curr. Microbiol. App. Sci. 3(12): 753.
- Burg, M.B. and Ferraris, J.D. (2008):. Intracellular organic osmolytes: function and regulation. $\mathrm{J}$ Biol. Chem., 283 (12): 7309.

- Chen, G.-Q. and Patel, M.K. (2012): Plastics derived from biological sources: present and future: a technical and environmental review. Chem. Rev., 112 (4): 2082.

- Chen, Q.; Zhang, L.; Li, X.; Liu, S. and Li, D. (2014): Poly- $\beta$-hydroxybutyrate/ectoine co-production by ectoine-excreting strain Halomonas salina. Process Biochem., 49 (1): 33.

- Czech, L.; Hermann, L.; Stöveken, N.; Richter, A.; Höppner, A.; Smits, S.; Heider, J. and Bremer, E. (2018): Role of the extremolytes ectoine and hydroxyectoine as stress protectants and nutrients: genetics, phylogenomics, biochemistry, and structural analysis. Gene, 9 (4): 177.

- Dawson, R. M. C.; Elliot, D. C. and Jones, K. M. (1986): Data for biomedical research $\left(1^{\text {st }}\right.$ ed.). UK: Clarendon Press.

- Donelli, G.; Vuotto, C. and Mastromarino, P. (2013): Phenotyping and genotyping are both essential to identify and classify a probiotic microorganism. Microb. Ecol. Health Dis., 24 (1): 20105.

- Elbanna, K.; Ibrahim, I.M. and Revol-Junelles, A.M. (2015): Purification and characterization of halo-alkali-thermophilic protease from Halobacterium $s p$. strain HP25 isolated from raw salt, Lake Qarun, Fayoum, Egypt. Extremophiles, 19 (4):763.

- Eshinimaev, B.T.; Tsyrenzhapova, I.S.; Khmelenina, V.N. and Trotsenko, Y.A. (2007): Measurement of the content of the osmoprotectant ectoine in methylotrophic bacteria by means of normal-phase high performance liquid chromatography. Appl. Biochem. Microbiol., 43 (2): 193.

- Gao, S.; Zhang, L.; Li, D.; Liu, S. and Li, X. (2014): Comparison of ectoine synthesis regulation in secreting and non-secreting strains of Halomonas. Ann. Microbiol., 64 (3): 1357. 
- Grote, M.; Engelhard, M. and Hegemann, P. (2014): Of ion pumps, sensors and channels-Perspectives on microbial rhodopsins between science and history. Biochim. Biophys. Acta (BBA)-Bioenergetics, 1837 (5): 533.

- Gudmalwar, R.M. and Kamble, L.H. (2014): Microbial Production of Poly-3-Hydroxyl Butyrate. Int. J. Adv. Biotechnol. Res, 15 (4): 717.

- Hassan, A.A. and Mahgoub, S.A. (2016): Salt inducible-proteins and conjugal gene transfer of halotolerant Staphylococcus isolated from salinity soil. Egypt. J. Genet. Cytol., 40 (2): 263.

- Heldman, D.R.; Hoover, D.G. and Wheeler, M.B. (2010): Encyclopedia of biotechnology in agriculture and food edition). CRC Press.

- Joghee, N.N. and Jayaraman, G. (2016): Biochemical changes induced by salt stress in halotolerant bacterial isolates are media dependent as well as species specific. Prep. Biochem. Biotechnol., 46 (1): 8.

- Kondepudi, K.K. and Chandra, T. (2011): Identification of osmolytes from a moderately halophilic and amylolytic Bacillus sp. strain TSCVKK. Eur. J. Exper. Biol., 1(1): 113.

- Kuhlmann, A.U.; Hoffmann, T.; Bursy, J.; Jebbar, M. and Bremer, E. (2011): Ectoine and hydroxyectoine as protectants against osmotic and cold stress: uptake through the SigB-controlled betaine-cholinecarnitine transporter-type carrier EctT from Virgibacillus pantothenticus. J. Bacteriol., 193 (18): 4699.

- Lentzen, G. and Schwarz, T. (2006): Extremolytes: natural compounds from extremophiles for versatile applications. Appl. Microbiol. Biotechnol., 72 (4): 623.

- Margesin, R. and Schinner, F. (2001): Potential of halotolerant and halophilic microorganisms for biotechnology. Extremophiles, 5 (2): 73.

- Mothes, G.; Schubert, T.; Harms, H. and Maskow, T. (2008): Biotechnological coproduction of compatible solutes and polyhydroxyalkanoates using the genus Halomonas. Eng. Life Sci., 8 (6): 658.
- Motta, A.; Romano, I. and Gambacorta, A. (2004): Rapid and sensitive NMR method for osmolyte determination. J. Microbiol. Meth., 58 (2): 289.

- $\quad$ Nada, A.; Refaat, M.; Abdel-Sabour, M.; Hassan, A. and Kader, M. (2011): Molecular studies on EctC gene (Ectoine) in some halophilic bacterial isolates. Researcher, 3 (2): 34.

- Nessim, R.B.; Tadros, H.R.Z.; Abou Taleb, A.E.A. and Moawad, M.N. (2015): Chemistry of the Egyptian Mediterranean coastal waters. Egypt. J. Aquatic Res., 41 (1): 1.

- Ongagna-Yhombi, S.Y. and Boyd, E.F. (2013): Biosynthesis of the osmoprotectant ectoine, but not glycine betaine, is critical for survival of osmotically stressed Vibrio parahaemolyticus cells. Appl. Environ. Microbiol., 79 (16): 5038.

- Ono, H.; Okuda, M.; Tongpim, S.; Imai, K.; Shinmyo, A.; Sakuda, S.; Kaneko, Y.; Murooka, Y. and Takano, M. (1998): Accumulation of compatible solutes, ectoine and hydroxyectoine, in a moderate halophile, Halomonas elongata $\mathrm{KS} 3$ isolated from dry salty land in Thailand. J. Ferment. Bioeng., 85 (4): 362.

- Onraedt, A.E.; Walcarius, B.A.; Soetaert, W.K. and Vandamme, E.J. (2005): Optimization of ectoine synthesis through fed-batch fermentation of Brevibacterium epidermis. Biotechnol. Prog, 21 (4):1206-12.

- Orellana, R.; Macaya, C.; Bravo, G.; Dorochesi, F.; Cumsille, A.; Valencia, R.; Rojas, C. and Seeger, M. (2018): Living at the Frontiers of Life: Extremophiles in Chile and Their Potential for Bioremediation. Front Microbiol., 9: 2309.

- Oren, A. (2006): Halophilic microorganisms and their environments. Springer Science \& Business Media.

- Osman, O.; Tanabe-Hosoi, S. and Nagata, S. (2009): Effect of osmotic downshock treatment on the yield of ectione synthesized by Halomonas $s p$. EG6. Nat. Res. Environ. Issues, 15, Article 29. https:// digitalcommons.usu.edu/nrei/vol15/iss1/29 
- Quillaguamán, J.;Hatti-Kaul, R.;Mattiasson, B.;Alvarez, M.T. and Delgado, O. (2004): Halomonas boliviensis sp. nov., an alkalitolerant, moderate halophile isolated from soil around a Bolivian hypersaline lake. Int. J. Syst. Evol. Microbiol., 54 (3):721-725.

- Reddy, N. R., Palmer, J. K., Pierson, M. D. and Bothast, R. J. (1983): Wheat straw hemicelluloses: composition and fermentation. J. Agric. Food Chem., 13, 1308e1313.

- Rezaei, S.M.; Shavandi, M.; Dastgheib, S.M.M. and Amoozegar, M.A. (2018): Bioremediation of oil-based drill cuttings by a halophilic consortium isolated from oil-contaminated saline soil. Biotechnol., 8: 1 .

- Roberts, M.F. (2005): Organic compatible solutes of halotolerant and halophilic microorganisms. Saline syst., 1 (1): 5.

- Rohban, R.; Amoozegar, M.A. and Ventosa, A. (2009): Screening and isolation of halophilic bacteria producing extracellular hydrolyses from Howz Soltan Lake, Iran. J. Ind. Microbiol. Biotechnol., 36 (3): 333.

- Romano, I.; Orlando, P.; Gambacorta, A.; Nicolaus, B.; Dipasquale, L.; Pascual, J.; Giordano, A. and Lama, L. (2011): Salinivibrio sharmensis sp. nov., a novel haloalkaliphilic bacterium from a saline lake in Ras Mohammed Park (Egypt). Extremophiles, 15 (2): 213.

- Rui-Feng, C.; Li-Huo, L.; Su, Y.; Li-Jun, Z.; Bin, L. and Jun-Qing, Q. (2017): Purification of (S)2-methyl-1, 4, 5, 6-tetrahydropyrimidine-4 carboxylic acid from Halophiles. Biomed. Res., 28 (12): 5511.

- Sauer, T. and Galinski, E.A. (1998): Bacterial milking: A novel bioprocess for production of compatible solutes. Biotechnol. Bioeng., 57 (3): 306.

- Setati, M.E. (2010): Diversity and industrial potential of hydrolase producing halophilic/halotolerant eubacteria. Afr. J. Biotechnol., 9 (11): 1555.

- Shivanand, P. and Mugeraya, G. (2011): Halophilic bacteria and their compatible solutes - osmoregulation and potential applications. Curr. Sci., 100 (10): 1516.

- Taher, A.G. (1999). Inland saline lakes of Wadi El Natrun depression, Egypt. Int. J. Salt Lake Res., 8 (2): 149.
- Tanne, C.; Meffert, A.; Golovina, E.A.; Hoekstra, F.A. and Galinski, E.A. (2014): Glass-forming property of hydroxyectoine is the cause of its superior function as a desiccation protectant. Front. Microbiol., 5:150.

- Teixidó, N.; Cañamás, T.; Usall, J.; Torres, R.; Magan, N. and Viñas, I. (2005): Accumulation of the compatible solutes, glycine-betaine and ectoine, in osmotic stress adaptation and heat shock cross-protection in the biocontrol agent Pantoea agglomerans CPA-2. Lett. Appl. Microbiol., 41: 248.

- Vaidya, S.; Dev, K. and Sourirajan, A. (2018): Distinct osmoadaptation strategies in the strict halophilic and halotolerant bacteria isolated from Lunsu salt water body of North West Himalayas. Curr. Microbiol., 75(7): 888 .

- Van-Thuoc, D.; Guzmán, H.; Thi-Hang, M. and Hatti-Kaul, R. (2010): Ectoine production by Halomonas boliviensis: optimization using response surface methodology. Mar. Biotechnol., 12 (5): 586.

- Vargas, C.; Jebbar, M.; Carrasco, R.; Blanco, C.; Calderon, M.I.; Iglesias-Guerra, F. and Nieto, J.J. (2006): Ectoines as compatible solutes and carbon and energy sources for the halophilic bacterium Chromohalobacter salexigens. J. Appl. Microbiol., 100 (1): 98.

- Ventosa, A.; Nieto, J.J. and Oren, A. (1998): Biology of moderately halophilic aerobic bacteria. Microbiol. Mol. Biol. Rev., 62 (2): 504.

- Wang, G. C. Y., and Y. Wang. (1996): The frequency of chimeric molecules as a consequence of PCR co-amplification of 16S rRNA genes from different bacterial species. Microbiology ,142: 1107.

- Yeung, S.N.; Butler, A. and Mackenzie, P.J. (2009): Applications of the polymerase chain reaction in clinical ophthalmology. Can. J. Ophthalmol., 44 (1): 23.

- Zhu, D.; Niu, L.; Wang, C. and Nagata, S. (2007): Isolation and characterisation of moderately halophilic bacterium Halomonas ventosae DL7 synthesizing ectoine as compatible solute. Ann. Microbiol., 57 (3): 401. 